Arab Univ. J. Agric. Sci., Ain Shams Univ., Cairo, 14(1), 59-70, 2006

\title{
VARIATION OF THREE BLACK CUMIN CULTIVARS IN HER- ITABILITY; CHEMICAL AND ANTIVIRAL ACTIVITY
}

[4]

\author{
Korkar $^{1}$, H.M.; Hanaa, H.A. Gomaa ${ }^{2}$ and Kh.A. El-Dougdoug ${ }^{3}$
}

\begin{abstract}
Black cumin is one of the important medicinal plant and well known to flok remedy. Balady, Sori and Turki cultivars belong to black cumin are variated in chemical composition and antiviral activity. The results reflected significant heritability between the three cultivars in length and number of capsule per plant and number of branches per plant, while non-significant values of plant height, number of locules capsule, and seed yield per plant. Eight fatty acids methyl esters were detected in seeds of three cultivars by GLC. It was found change quantitatively of fatty acid between three cultivars. SDS-PAGA showed change qualitatively of poly peptides content accompanying three cultivars. A similarity of about $90 \%$ was found between Balady and Sori cultivars in relation to heritability. Water seed extracts, in vitro reduced ToMV infectivity to $6.73 ; 6.78$ and $5.08 \%$ of Balady, Sori and Turki respectively. Four hours post and pre ToMV inoculation were most sensitive period to ToMV replication for three cultivars. On the other hand, the antiviral event changed in conformation and chemical structure of virion, coat protein and nucleic acid of ToMV with black cumin seed extract by spectroscopy. Balady, Sori and Turki; black cumin cultivars were varieted based on heritiability, chemical composition according to fatty acid GLC and polypeptide fraction SDS-PAGE analysis as well as antiviral activities against tomato mosaic tobamovirus.
\end{abstract}

Keywords: Black cumin, Fatty acids, Polypeptide fraction, SDS-PAGE, Antiviral, Tomato mosaic virus (ToMV)

\section{INTRODUCTION}

Black cumin Nigella sativa $\mathrm{L}$ is an herbaceous plant belong to family Ranun- culuceae. The plant has a long history of flok medicine. The seeds are used as a carminative, diuretic and useful for asthma.Many authers studied the genetic var-

1- Applied and Basic Agric. Science Department, High Institute for Agricultural Cooperation, Shobra El-Kheima, Cairo, Egypt

2- Department of Botany, Faculty of Science, Suez Canal University, Ismailia, Egypt

3- Department of Agric. Microbiology, Faculty of Agriculture, Ain Shams University, Shobra El-Kheima, Cairo, Egypt

(Received September 7, 2005)

(Accepted November 14, 2005) 
iability of black cumin cultivars (Banafar et al 2002 and D'Antuono et al 2002) and heritability, variation and correlation coefficient among nigella characters (Salem et al 2001). Morever, fatty acids methyl esters and sterols olated from nigella seeds were studied by Perifanova $\boldsymbol{e t}$ al (2002) and Atta, (2003). It was previously reported that extracts of mature leaves, roots, stems and seeds of plants inhibited to varying degrees, however, this is true only when they were mixed with the virus prior to inoculation or applied to leaves within a short time before or after virus inoculation (El-Dougdoug, 1997). The effect of plants extracts was attributed to their chemical contents as antiviral agent such as phenolic components (Woods and Agrios, 1973); Steroids, (Menzel, 1987) alkaloids (Attaur-Rahaman et al 1985) and protein (Othman et al 1991).

The present study aim to evaluate the heritability, chemical composition among black cumin cultivars and to investigate the antiviral activity of their cultivars extracts against tomato mosaic tobamovirus.

\section{MATERIAL AND METHODS}

\section{Plant material}

The plant material used in this study is seed of three cultivars of Nigella (Balady, Sori, and Turki) were obtained from Genetic and Breeding of Medicinal and Aromatic plants Group, Genetic and Cytology Department National Research Center.

\section{Virus source}

Tomato mosaic tobamovirus (ToMV) was obtained from virology lab. Microbiology Department, Faculy of Agriculture. Ain Shams Univ. maintenance on Nico- tina tabacum cv. Samson as well purified ToMV virus particles.

\section{Experimental form}

Seeds were sown in hill $30 \mathrm{~cm}$ space of lines $5 \mathrm{~m}$ long $50 \mathrm{~cm}$ wide. Five replicates of each cultivar were designed in three complete blocks at farm faculty of Agriculture, Ain Shams Univ. All culture practices were carried out. At maturity, the plants were harvested, separately. The plant height, number of branches and capsule, seed yield per plant, capsule length, and diameter as well number of locules per capsule were recorded. The obtained data were statistically analyzed according to Steel and Torrie (1980).

\section{Crude water extract}

Water extracts of three cultivars of (Nigella sativa L.) were reported by macerating, one gram fine powder seeds with $9 \mathrm{ml}$ distilled water at water bath, then distilled water was add at reach $1 / 10$ $(\mathrm{w} / \mathrm{v})$. Petroleum ether $\left(40-60^{\circ} \mathrm{C}\right)$ used for seed extraction according to the procedure carried out Ottai, (1994). The fatty acid methyl esters were prepared from Petroleum ether extracts by the method of Vogel, (1975). Then quantitative analysis of the fatty acid esters for three cutivars were performed with Gas liquid chromatography (GLC)using Sp. 2310 Column 55\% Cyanopropyl phenyl silicon dimensions $1.5 \times 4 \mathrm{~mm}$. The temperature propram was $70^{\circ} \mathrm{C}$ (initial temperatures) at a role of $8^{\circ} \mathrm{C} / \mathrm{min}$. to $190^{\circ} \mathrm{C}$ (final temperature). Injector and detector temperatures were mentained at 250 and $300^{\circ} \mathrm{C}$ respectively. Nitrogen was used as carrier gas at a rate of $30 \mathrm{ml} / \mathrm{min}$. The relative percentage of each compound was determined on the base of the peak area. The 
qualitative identification of fatty acids were achieved by comparing the retention time (Rt) of their expected authentics chromatographed under the same conditions.

\section{Electrophoretic analysis}

Sodium dodecyl sulphatepolyacreylamide gel electrophoresis (SDS-PAGA) was performed in $12.5 \%$ acrylamide (w/v) slab gel containing sodium dodecyl sulphate (SDS) (Laemmli, 1970). The gels were cross linked with $0.3 \%(\mathrm{w} / \mathrm{v}) \mathrm{N}, \mathrm{N}$-methylene bis-acrylamide at $\mathrm{pH} 8.8$ and stacking gels were made $5.0 \%(\mathrm{w} / \mathrm{v})$ polyacreylamide at $\mathrm{pH}$ 6.8. Samples $(50 \mu \mathrm{l})$ were denaturated by boiling buffer at $100^{\circ} \mathrm{C}$ for $10 \mathrm{~min}$. in $1 \%$ SDS containing 2-mercaptoethanol. Molecular weights of the protein fractions were estimated from a low molecular weight standard (Pharmacia Motreal) electrophoreses under identical condition. Marker protein for molecular weight measurement were: 97.400; 58.100; 39.800; 29.000; 20.100; and $14.300 \mathrm{KDa}$.

\section{Assay of antiviral activity}

In vitro Mixing $1.0 \mathrm{ml}$ of infected crude sap with $1.0 \mathrm{ml}$ crude extracts of three cultivars. The mixtures were inoculated at lab. temperature $\left(25^{\circ} \mathrm{C} \pm 2^{\circ} \mathrm{C}\right)$ for $0 ; 1$ and $24 \mathrm{hr}$. The control was carried out with distilled water. The inhibitory effect on virus infectivity was assayed by local lesion assay (applied $100 \mu \mathrm{l}$ inoculum) on N. glutinosa.

In vivo This experiment was carried by rubbing of $N$.glutinosa leaves ( $1 \mathrm{ml} /$ leave) with crude extract of three varieties pre and post virus inoculation $(50 \mu \mathrm{l} /$ leaves $)$ using glass spatula. The experiment control was carried out with distilled water. The inhibitory effect was calculated according to the formula $\mathrm{I}=(1-\mathrm{C} / \mathrm{Co}) \mathrm{x}$ 100 , where $\mathrm{I}=$ percentage of infection $\mathrm{C}=$ number of local lesions of treatment and $\mathrm{Co}=$ number of local lesions of the control. The relative inhibition was calculated as the difference in number of local lesions produced between treatment and control. Multiplied by 100 and divided by number of local lesions of control.

\section{Effect of black cumin water seed ex- tract on virus particles and protein preparation}

The RNA was prepared from ToMV particles by repeated chloroform-phenol extraction. The pellet containing RNA was resuspended in $0.1 \mathrm{M}$ Tris $\mathrm{pH} 8.0$ and $0.01 \mathrm{M}$ EDTA and stored at $-20^{\circ} \mathrm{C}$. the supernatant containing protein was separated by the acetic acid (Sambrook, 1989).

The effect of seed extracts on RNA, protein, and virion was spectrophotomatically determined by mixing $50 \mu$ of each them with $50 \mu$ l of seeds extracts for three cultivars. The three mixtures were determined using UV-Vis spectrophotometer, Shimadizo 1201 program Photometric 2 at $260 \mathrm{~nm}$ for RNA and virion and 280 $\mathrm{nm}$ for protein at different times intervals $5 \mathrm{~min}$. through 45 mins.

\section{RESULTS AND DISCUSSION}

The analysis of variation between the cultivars of black cumin (Balady, Sori and Turki) is presented in Table (1). Highly significant variability were noted 
Table 1.Variation of morphological characters for three black cumin cultivars

\begin{tabular}{|c|c|c|c|c|}
\hline \begin{tabular}{|lr} 
& Cultivars \\
Morphological character & \\
\end{tabular} & Balady & Sori & Turki & $\begin{array}{c}\text { L.S.D } \\
(1 \%)\end{array}$ \\
\hline Plant height (cm) & 65.50 & 52.50 & 40.25 & 10.5 \\
\hline No. of branches $(\mathrm{cm})$ & 13.75 & 15.25 & 10.50 & 2.4 \\
\hline Capsules length (cm) & 1.50 & 1.25 & 1.35 & 0.25 \\
\hline Capsules diameter $(\mathrm{cm})$ & 1.00 & 0.92 & 0.89 & Ns \\
\hline No. of capsule/plant & 75.0 & 45.25 & 37.25 & 11.2 \\
\hline No. of locules/capsule & 6.50 & 7.21 & 5.75 & 0.75 \\
\hline Seed yield/plant (g) & 8.00 & 3.50 & 4.00 & 2.5 \\
\hline
\end{tabular}

Average from 10 replicates

$\mathrm{Ns}=$ non significance

for plant height, number of branches, capsules and seed yield per plant, as well as capsule length addition to, variations in capsules diameter and number of locules per capsule. These results are agreement with those of Salem et al (2001). Banafar et al (2002). There are found that high heritability values for capsule length, number of branches and capsules per plant, while moderate values for other characters. Balady was found to be the best cultivar in the most of trails and it had homogentical plants. Different pattern of phenotypic correlation were noted between each cultivar characters. Figure (1) refers to the peaks obtained using GLC which resulted qualitative and quantitative analysis of methyl esters fatty acids based on the area under peak. The relative percentages of the detected fatty acids extracted from the petroleum ether are shown in Table (2) and Figure (1) three cultivars. Eight fatty acid were determined in the three cultivars. Unsaturated fatty acids were found with major amounts 52.84, 61.95 and 69.67 as well saturated fatty acids were found with minor amount 47.16; 38.05 and 29.83 in Balady; Sori and Turki cultivars respectively.Fatty acid quantitative were differed between the three cultivars. Caprylic and Capric acids were found high relative percentage in Balady 10.40, 5.70 followed by Sori 4.24, 2.85, while trace and 1.16 in Turki cutivars respectively. Stearic was found high relative percentage in Sori 2.78 followed by Balday 1.92 and trace in Turki cultivars. Other fatty acids were found with relative percentage differential between three cultivars. These results were in good agreement with those of Mona Ahmed (1991); Ozguven et al (2001); Ramadan and Morsel (2002). The polypeptides from various subcellullar fractions of black cumin seeds were analyzed by SDS- PAGE under reducing conditions (Figure 2). The polypeptide patterns of cultivars varied in number and molecular 
Table 2. GIC anaylsis of fatty acids for three black cumin cultivars

\begin{tabular}{|lccc|}
\hline \multicolumn{1}{c}{ Cultivars } & Balady & Sori & Turki \\
Fatty acids component & & & \\
\hline \multicolumn{1}{|c|}{ Saturated fatty acids } & & & \\
palmitic & 13.60 & 14.15 & 12.40 \\
Arachidic & 11.12 & 8.20 & 11.54 \\
Myristic & 4.42 & 5.83 & 4.75 \\
Capric & 5.70 & 2.85 & 1.16 \\
Stearic & 1.92 & 2.78 & Trace \\
Caprylic & 10.40 & 4.24 & Trace \\
\hline Total & 47.16 & 38.05 & 29.83 \\
\hline \multicolumn{1}{|c}{ Unsaturated fatty acids } & & & \\
Linoleic & 32.42 & 34.83 & 38.42 \\
Oleic & 20.42 & 27.12 & 31.25 \\
\hline Total & 52.84 & 61.95 & 69.67 \\
\hline Total fatty acids & 100 & 100 & 99.50 \\
\hline
\end{tabular}

97.400

58.100

39.800

29.000

20.000

14.300

Figure 2. SDS-polyacrylamide gel (12.5\%) electrophoresis of black cumin seeds polypeptides from three culivars Balady, Sori and Turki.

Arab Univ. J. Agric. Sci., 14(1), 2006 
weight, the alteration detected the polypeptide patterns as judged by staining appears in the enhancement 87.50 and 39.3 KDa in Balady and Sori than Turki cultivars. However 77.75, 58.10, 14.30 and $12.0 \mathrm{KDa}$ common polypeptides were detected in three cultivars. Babayan et al (1978) and Aly et al (1994) reported that the analysis of Nigella sativa L. seeds contained $21 \%$ protein.

\section{Effect of seed extracts on ToMV infec- tivity}

In vitro It was found that the seed extracts at dilution $10^{-1}$ had the high effect on ToMV infectivity where as reduced the number of local lesions $N$. glutinosa, Table (3). The reduction reached to maximum after $24 \mathrm{hrs}$ inoculation. Sori var. had the least effect on virus infectivity and inhibitory effect, while Balady and Turki had highest effects.

In vivo In post virus inoculation, It was clear that the seed extracts were effective virus infectivity after $1 / 2,1$ and $4 \mathrm{hrs}$. These periods gave the best results concerning the infectivity and inhibition i.e. it gave the lowest number of local lesions.

On the other hand the infectivity was increased again by increasing the period. up to $24 \mathrm{hr}$ (Table 4). Within each period the seed extracts of var. Balady dose not regularity reduce the ToMV infectivity and increases the inhibitory effect. From the result in Table (4), it was found that, the seed extract have inhibitory effect on ToMV through eclipse period (1/2hr) and multiplication (1-4hr, from ToMV penetration to translocation in $N$. glutinosa).

In pre- virus inoculation, the seed extracts of Balady cultivar had the inhibitory effect on ToMV infectivity. High re- duction in number of local lesions on $N$. glutinosa leaves which sprayed with seed extracts of cultivar Balady before virus inoculation. The inhibitory effect tends to decrease by increasing time (1-24hr) (Table 4). Generally, the rubbing with water extracts of black cumin seeds before virus inoculation, was more effective in reducing ToMV infectivity than after ToMV inoculation.

The water extract of black cumin seeds included more virus inhibitors such as alkaloids, sterols, saponin, and nigellicine (Attaur-Rohman et al 1985). The inhibitory effect was attributed to chemical content of seed extracts as antivirals interfere with the host defense mechanism associated with the precipitation of the virus in bands such bands may not be infectious or may behave as one virus particles (Mayer et al 1995). Indeed, there results shown that following infection with ToMV, the microsomal RNA of the host is rapidly degraded and its degradation products are utilized in the virus synthesis. It was further demonstrated by authers (Kiraly and Pazsar, 1964). Similarly, the results suggested that, the protein of ToMV is formed at the expense of an electrophoretically homogenous protein of tomato leaves. This protein fraction is degraded after infection as virus protein is synthesized (El-Dougdoug, 1997).

Results in Table (5) illustrate the effect of black cumin on UV absorption rate of virion, genome (RNA) and coat protein, as well as effect on concentration and conformation of chemical composition of ToMV at 45 mins It was found that the maximum effect on virion and coat protein after 20 mins and genome(RNA) after 15 mins. 
Table 3. Inhibitory effect of water seed extract (Black cumin cultivars) on ToMV infectivity in vitro

\begin{tabular}{|lcccccccccc|}
\hline & \multicolumn{3}{c}{ P-time } & \multicolumn{3}{c}{ 1-hr } & \multicolumn{3}{c|}{$24 \mathrm{hr}$} \\
\cline { 2 - 11 } & $\begin{array}{c}\text { No. } \\
\text { of } \\
\text { L.L }\end{array}$ & $\begin{array}{c}\text { \% of } \\
\text { inf. }\end{array}$ & $\begin{array}{c}\text { Inhib- } \\
\text { itory } \\
\text { effect }\end{array}$ & $\begin{array}{c}\text { No. } \\
\text { of } \\
\text { L.L }\end{array}$ & $\begin{array}{c}\% \\
\text { of } \\
\text { inf. }\end{array}$ & $\begin{array}{c}\text { Inhibitory } \\
\text { effect }\end{array}$ & $\begin{array}{c}\text { No. } \\
\text { of } \\
\text { L.L }\end{array}$ & $\begin{array}{c}\% \\
\text { of } \\
\text { inf. }\end{array}$ & $\begin{array}{c}\text { Inhibitory } \\
\text { effect }\end{array}$ \\
\hline ToMV crude sap & 90 & 100 & - & 85 & 100 & - & 85 & 100 & - \\
\hline $\begin{array}{l}\text { ToMV treated } \\
\text { with black cumin } \\
\text { cultivars: }\end{array}$ & & & & & & & & & \\
$\quad \begin{array}{l}\text { Balady } \\
\text { Sori }\end{array}$ & 16.5 & 18.33 & 81.67 & 11.5 & 13.53 & 86.47 & 5.72 & 6.73 & 93.27 \\
\multicolumn{1}{l}{ Turki } & 20.7 & 23.00 & 77.00 & 12.7 & 14.94 & 85.06 & 5.25 & 6.18 & 93.82 \\
\hline
\end{tabular}

No. of local lesions (L.L) calculated from five replicates of $N$. glutinosa

$\%$ of virus infectivity calculated (base on control $100 \%$ )

Table 4. Inhibitory effect of water seed extract (Black cumin cultivar Balady) on ToMV infectivity in vivo

\begin{tabular}{|c|c|c|c|c|c|c|}
\hline \multirow[b]{2}{*}{ Treatment } & \multicolumn{3}{|c|}{ Post- inoculation } & \multicolumn{3}{|c|}{ Pre- inoculation } \\
\hline & $\begin{array}{c}\text { No. of } \\
\text { local } \\
\text { lesions }\end{array}$ & $\begin{array}{c}\% \text { of } \\
\text { infectivity }\end{array}$ & $\begin{array}{c}\text { Inhibitory } \\
\text { effect }\end{array}$ & $\begin{array}{l}\text { No. of } \\
\text { local } \\
\text { lesions }\end{array}$ & $\begin{array}{c}\% \text { of } \\
\text { infectivity }\end{array}$ & $\begin{array}{c}\text { Inhibitory } \\
\text { effect }\end{array}$ \\
\hline $\begin{array}{l}\text { Inoculated plants and } \\
\text { sprayed with water } \\
\text { (control) }\end{array}$ & 95 & 100 & - & 80 & 100 & - \\
\hline \multicolumn{7}{|l|}{$\begin{array}{l}\text { Inoculated plants and } \\
\text { sprayed with black } \\
\text { cumin (Balady): }\end{array}$} \\
\hline 0-time & 35.12 & 36.97 & 63.03 & 7.25 & 9.06 & 90.94 \\
\hline $1 / 2 \mathrm{hr}$ & 10.15 & 10.68 & 89.32 & 9.00 & 11.25 & 88.75 \\
\hline $1 \mathrm{hr}$ & 12.31 & 12.95 & 87.64 & 10.23 & 12.79 & 87.21 \\
\hline $4 \mathrm{hr}$ & 10.25 & 10.80 & 89.21 & 15.45 & 19.31 & 80.69 \\
\hline $24 \mathrm{hr}$ & 30.75 & 32.37 & 67.63 & 22.73 & 28.41 & 71.59 \\
\hline $48 \mathrm{hr}$ & 25.72 & 27.07 & 72.93 & 30.82 & 38.53 & 61.48 \\
\hline
\end{tabular}

Arab Univ. J. Agric. Sci., 14(1), 2006 
Arab Univ. J. Agric. Sci., 14(1), 2006 
El-Dougdoug, (1997) reported that, the seed extracts of Khella and black cumin event changing in conformation and chemical structure of ToMV virion, coat protein and RNA of ToMV by spectroscopy. Furthermore black cumin are much more affective against protein synthesis (Menzel, et al 1987) and nucleic acid (Yordanova, et al 1996).

\section{REFERENCES}

Aly, M.S.; E.E. Habaa and M.D. Khattab (1994). Molybedienum effect on chemical constitutents of Nigella sativa L. seeds. J. Agric. Sci., Mansoura Uuniv., 19(9): 2981-2989.

Attaur-Rahman, M.S.; He-Cunheg and J. Clordy (1985). Isolation and structure determination of nigellicine, a novel alkaloid from the seed of Nigella sativa. Tetrahedron Letters. 26(23): 2759-2762.

Atta, M.B. (2003). Some characteristics of Nigella (Nigella sativa L.) seed cultivated in Egypt and its lipid profile. Food Chemistery 83(1): 63-68.

Babayan, K.V.; D. Koottungal and G.A. Halaby (1978). Proximate analysis, fatty acid and amino acid composition of Nigella sativa L. seeds. J. of Food Sci., 43:1314-18.

Banafar, R.N.S.; N.K. Gupta and A.C. Pathak (2002). Suitability of Black cumin varieties (Nigella sativa L.) for Modhya Pardesh. Advances in Plant Sciences, 15(1): 165-166.

D'Antuono, L.F.; A. Moretti and A.F.S. Lovato (2002). Seed yield, yield component, oil content and essential oil content and composition of Nigella sativa L. and Nigella damascana L. Industrial Crops and Products. 15(1): 59-69.
El-Dougdoug, Kh.A. (1997). Antiphytoviral Activity of Khella and black cumin on infectivity and chemical structure of Tomato mosic virus (ToMV). Proceeding of the $9^{\text {th }}$ Conference of Microbiology, Egypt. Soc. Of Microbology, Cairo, pp. 25-27.

Kiraly, Z. and B.I. Pazsar (1964). On inhibition of TMV production by Kinetin and Adenine in the intact tobacco leaves. Reprint from the Proceedings of the Symptom on Host. Parasite Relations in Plant pathology, Budapest, pp. 61-64.

Laemmli, U.K. (1970). Cleavage of structural proteins during the assembly of the head of bacteriophage $\mathrm{T}_{2}$. Nature 227: 680-685.

Mayer, C.; Dan, De and Z. Allan (1995). Antiviral protein in higher plants. Library of Congress. Cataloying in Publication Date Raton Ann. Arab. London Tokyo. pp. 119-130.

Menzel, G.; S. Kluge and H.P. Kertscher (1987). The sterols of Nigella sativa seed oil. Photochemistry 25(3): 761-762.

Mona, Y.Kh. Ahmed (1991). Biochemical and Physiological Studies on Some Aromatic Plants. p. 111. M.Sc. Thesis Fac. Agric. Cairo University.

Noordam, D. (1973). Identification of Plant Viruses Methods and Experiments. pp. 75-103. Center for Agriculture Publishing and demonstration (Pudoc) Wageningen.

Othman, B.A.; Kh.A. El-Dougdoug and M. Abo-El-Naser, (1991). Effect of garlic bubbilies extraction on tomato mosaic virus. Annals Agric. Sci. Ain Shams Univ., Cairo 36: 2423-430.

Ottai, M.E.S. (1994). Preference of Stored Seed Insects Attacking Selected Medicinal Plant Species Germ-Plasm. 
p. 209. M.Sc. Thesis Fac. Agric., Ain shams Univ. Cairo, Egypt.

Ozguven, M.; M. Kirpik; W.D. Kaller; S. Kerschbaum; P. Range and $P$. Schweiger (2001). Yield and quality characteristics of black cumin (Nigella sativa L.) in the Cukurova region of South Turkey. Zeitschrift fur Arznei und Gewurzplanzen. 6(1): 20-24.

Perifanova-Nemska, M.; M. Zlatanova and F. Misilski (2002). Lipid composition of Nigella sativa L. seed oil Bulgarium. J. Agric. Sci., 8(1): 67-70.

Ramadan, M.F. and I.T. Morsel (2002). Neutral lipid classes of black cumin $(\mathrm{Ni}$ gella sativa L.) seed oils. European Food Research and Technology. 214(3): 202206.

Salem, A.G.; T.A. Tahu and L.A. Abou-El-Fadl (2001). Studies on variability, heritability and characters association in black cumin (Nigella sativa L.). Egypt J. Agric. Res., 19(4): 1439-1447.
Sambrook, Y.; E.F. Fritch and T. Manratis (1989). Molecular Cloning a Laboratory Manual $2^{\text {nd }}(E d$.$) p. 590$. Laboratory Press, Cold Spring, Harber, NY.

Steel, R.G.D. and J.H. Torrie, (1980). Principles and Procedures of Statistics. Mc. Graw-Hill Book Co., Inc. New York. Vogel, A.J. (1975). Practrical Organic Chemistry $3^{\text {rd }}$ (Ed.). 969 pp. Book Society and Longmans Group Ltd., London.

Wood, T.L. and G.N. Agrios (1973). Effect of oxidized phenolic compounds on the infectivity of cowpea chlorotic mottle virus ribonucleic acid. Phytopathology. 63, 209 Abstract.

Yordanova, A.; N. Korparova; E. Stomenova and $M$. Starcheva (1996). Antiphytoviral activity of 1Morpholinomethyl tetrahydro, 2(1-H) Pyrimidinone (DD13). Plant Pathology 45(3): 547-551. 


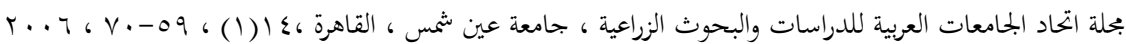
التباين الوراثى والكيماوى والنشاط المضاد للفيروس لأصناف حبة البركة

حسن محمود قرقار' - هناء حسين أحمد' - خالا عبد الفتاح الاجدج

1 - المعهـ العالـى للتعـاون الزراعسى - شبـرا الخيمـة - القاهــرة

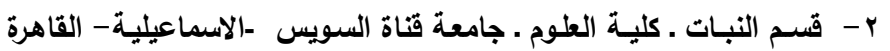

ب- قسم الميكروييولوجيا الزراعية ـ كلية الزراعة ـ جامعة عين شمس - شبرا الخيمة - القاهرة

تعتبر حبة البركة من أهم النباتات الطبية النتائج تشابـه بنسبة و\% بين الصنفين

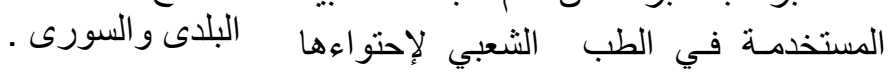

ثانياً: : أظهرت نتائج دراسة التباين الكيماوى اختلاف ملحوظ فى الأحماض الدهنية التى تم

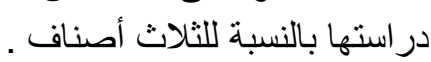
على أحماض دهنية ومكونات غير متصبنة

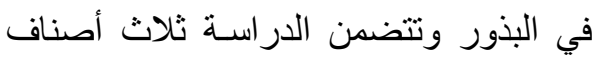
البلدي والسوري و التركي. و أظهرت النتائج

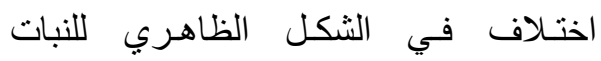
و التركيب الكيماوي للبذور وكذلك استخدام ثالثاً : استخدام المستخلص المائسى للبذور المستخلص المائي للبذور كمضاد للفيروس. كمضاد للفيروس أحدث اختز ال للإصسابة إلى : لإنى

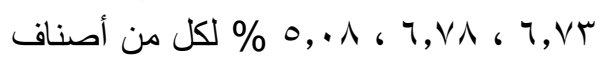

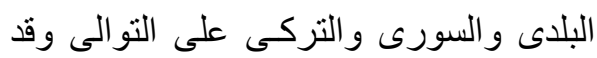
وتتلخص النتائج الار اسة فيما يلى

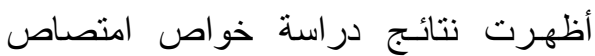
الأشعة فوق البنفسجية للمستخلص الفيروسى درس

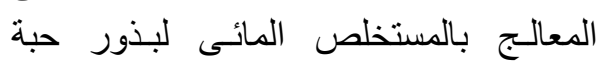

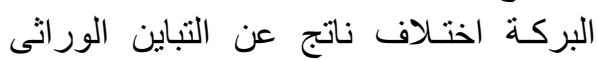
والتـركيب الكيمساوى للأحماض عن الدهنية اولا: عكس التباين الوراثى بين الثناث

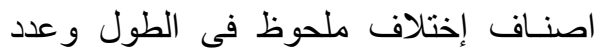

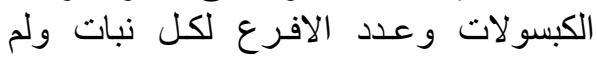

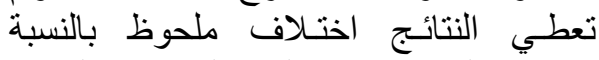

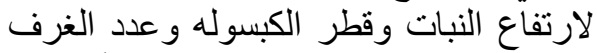
كمضاد للفيروس .

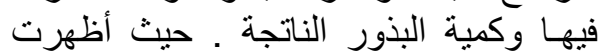

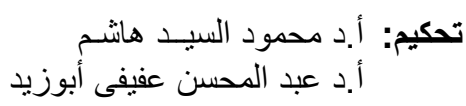

